\title{
Natural enemy diversity reduces temporal variability in wasp but not bee parasitism
}

\author{
Dorthe Veddeler $\cdot$ Jason Tylianakis $\cdot$ \\ Teja Tscharntke $\cdot$ Alexandra-Maria Klein
}

Received: 12 December 2008/Accepted: 13 October 2009/Published online: 19 November 2009

(C) The Author(s) 2009. This article is published with open access at Springerlink.com

\begin{abstract}
Biodiversity may enhance and stabilise ecosystem functioning, but little evidence exists for diversityfunction relationships involving multitrophic interactions in real landscapes. In multitrophic communities diversity may vary at different trophic levels, with either synergistic or antagonistic effects on ecosystem functioning. Intensification of land-use systems is often found to reduce diversity, which in turn may lead to reduced associated ecological functions in natural food webs, such as hostparasite interactions. In this study we investigated the relationship between the number of natural enemy and host species and the mean rate and temporal variability of parasitism (inverse of stability), along an intensification gradient of coffee agroforests in Ecuador. We used standardised trap nests for bees and wasps and their natural enemies in 14 agroforests, and evaluated these monthly over a period of 17 months. We found that parasitism rates of wasps and bees increased with increasing number of enemy species and decreased with increasing number of
\end{abstract}

Communicated by Jay Rosenheim.

\section{Present Address:}

D. Veddeler $(\bowtie)$

Institute of Ecology, University of Jena,

Dornburger Strasse 159, 07743 Jena, Germany

e-mail: dorthe.veddeler@web.de

Present Address:

J. Tylianakis

School of Biological Sciences, University of Canterbury,

Private Bag 4800, Christchurch 8020, New Zealand

T. Tscharntke $\cdot$ A.-M. Klein

Department of Crop Science (Agroecology Section),

University of Göttingen, Waldweg 26,

37073 Göttingen, Germany host species. Temporal variability in parasitism rates decreased with increasing number of enemy species and increased with temporal variability in enemy species richness; however, these effects were restricted to wasp hosts. Intensification of agroforests did not significantly affect species richness of hosts or enemies or their relation to parasitism and its temporal variability. We conclude that high enemy diversity may enhance parasitism rates and that high host diversity may provide resistance against consumption. Furthermore, we show that a diverse and stable enemy community may also have a stabilizing effect on parasitism rates. However, these effects may be host-guild specific, as these relations were restricted to wasps.

Keywords Land use - Biodiversity - Management . Pollinator · Predator

\section{Introduction}

The worldwide anthropogenic modification of habitats leads to a considerable loss of global and local biodiversity, which in turn may significantly alter ecosystem functions, including those important for human well-being (Daily et al. 1997; Diaz et al. 2006). To understand the functional consequences of species' extinctions, several studies have experimentally analysed the effects of diversity changes on ecosystem functioning by artificially manipulating diversity. These experiments were largely restricted to aquatic systems or terrestrial plant communities and a single trophic level (e.g. Tilman et al. 1996; Cardinale et al. 2008; Schmid et al. 2009). Natural ecosystems, however, are built of interactions across multiple trophic levels, which may influence the relationship between diversity and ecosystem function (Petchey et al. 2004; Thébault and Loreau 2006; 
Tylianakis et al. 2008). Diversity at one trophic level can affect diversity and abundance at adjacent levels through trophic interactions (Hooper et al. 2005; Thébault and Loreau 2005; Long et al. 2007). Yet, the few studies that have examined multitrophic interactions have mostly investigated the effects of diversity changes at the consumer level, while the diversity of prey has remained unmanipulated (e.g. Cardinale et al. 2003; Larsen et al. 2005; Snyder et al. 2006; but see Montoya et al. 2003; Gamfeldt et al. 2005). But changes in diversity, at both the prey and consumer level, could affect ecosystem functioning in a multitrophic system, either synergistically or antagonistically (Srivastava and Vellend 2005). The literature on the relationship between diversity and ecosystem functioning provides a broad theoretical framework for biodiversity effects on multitrophic systems. However, previous research has also examined the importance of predator and parasitoid diversity for prey/host suppression often in the context of biological pest control (Ehler 1992; Sih et al. 1998; Briggs and Latto 2000; Straub et al. 2008).

In this context, diversity may also stabilise ecosystem functioning in a multitrophic system (Srivastava and Vellend 2005; Long et al. 2007) by reducing variability in function over time. So far, few empirical results are available on the stabilizing effect of diversity on ecosystem functioning in non-experimental terrestrial multitrophic systems (Hooper et al. 2005; Thébault and Loreau 2005, 2006, Tylianakis et al. 2008), although trophic interactions can play an important part in community stability (Aoki and Mizushima 2001).

Consequently, it remains unclear whether diversityfunction relationships experimentally found for single trophic levels apply to multitrophic systems. From experimental manipulations some evidence exists for a diversityfunction relationship in multitrophic systems, such as herbivore control by enemies (Snyder et al. 2006) or marine microbial systems (Gamfeldt et al. 2005). However, empirical results from terrestrial, multitrophic systems are lacking. For example, land-use intensification, such as the conversion from traditional agroecosystems to intensified monocultures may change the diversity-function relationship. Environmental changes may affect species in a non-random manner, in contrast to the design of many experiments, but may select for certain species traits (Srivastava and Vellend 2005), and if the response traits are correlated with functional effect traits (Larsen et al. 2005) or highly functional species go extinct, then the effects of extinctions may differ from the effects of diversity in experimental studies.

Tylianakis et al. (2006) analysed the diversity-functionstability relationship in a multitrophic system of enemies and hosts of different land-use types, forming a strong gradient of anthropogenic modification from natural forests to rice fields in an open, intensified agricultural matrix.
They found a strong diversity-function relationship, which was constant across different land-use types, but land-use intensification strongly affected diversity and abundance of hosts and enemies, thereby indirectly affecting function rates.

However, it is not yet known if these stabilizing effects in parasitism can be also found in a single land-use system with less variation in diversity than would be seen across a land-use intensification gradient.

Traditional agroforests, such as diverse shaded coffee systems, are known to contain a high diversity of many taxa (Moguel and Toldeo 1999), and ecosystem function rates similar to those of natural forests (Tylianakis et al. 2006). However, these systems are increasingly converted to intensive sun monocultures or coffee managed under a single shade tree species. Several studies show that intensification of these systems significantly reduces their biodiversity (Mas and Dietsch 2003; Perfecto et al. 2003; Armbrecht et al. 2005; Philpott et al. 2008; Vergara and Badano 2008), which may also affect beneficial insects and associated ecological functions and services (Klein et al. 2003; Klein et al. 2006; Vergara and Badano 2008).

Bees and wasps found in trap nests made of reed internodes belong mainly to the bee family Megachilidae (leaf-cutting bees, larvae feed on pollen and nectar and can act as pollinators); the wasp families are Eumenidae (mason wasps, larvae feed mainly on various caterpillars and some species on aphids and other arthropods), Sphecidae (sand wasps, larvae feed on spiders), and Pompiliidae (spider wasps, larvae feed on spiders) (Gathmann 1998; Tscharntke et al. 1998; Tylianakis et al. 2005; Klein et al. 2006). Around 5\% of all bees and wasps are potential trap-nesting species (Gathmann 1998). Depending on the ecoregion, bees or wasps are the dominating group in trap nests. In general, it seems that the proportion of wasp- to bee-occupied brood cells is higher in tropical compared to temperate regions (e.g. compare studies of Tscharntke et al. 1998; Tylianakis et al. 2005; Klein et al. 2006).

Bees and wasps using trap nests are usually obligate cavity nesters with a solitary life cycle (Gathmann 1998). Depending on the climatic region, trap-nesting bees and wasps can bear one to several generations per year. Both functional groups are attacked by two groups of natural enemies, parasitoids and kleptoparasites. Parasitoids are mainly tiny wasps, e.g. of the families Braconidae, Chalcidoidae, Eulophidae, Ichneumonidae. The main parasitoid species found in trap nests in Ecuador is a cosmopolitan, gregarious ectoparasitoid Melittobia acasta (Walker) of the family Eulophidae (Tylianakis et al. 2005, 2006). Dominant kleptoparasites that do not directly feed on the bees and wasps but on their food resources are cuckoo wasps of the family Chrysididae. Besides the Hympenoptera, 
Diptera (bee flies, Bombyliidae and tachinid flies, Tachinidae) and Coleoptera (Dermestidae, Meloidae, Mordellidae) also feed on the larval food. Common kleptoparasites of bees only are the cuckoo bees of the genus Coelioxys (Tscharntke et al. 1998; Klein et al. 2006; Tylianakis et al. 2006).

We investigated multiple trophic levels in a coffee agroecosystem to address these questions:

1. Is diversity related both to mean function rates and the stability of an ecosystem function in a natural, multitrophic system?

2. Do diversity changes at different trophic levels in a multitrophic system have different effects on related functions?

3. Does land-use intensification within one land-use type alter these relationships?

To answer these questions we analysed the community of trap-nesting bees and wasps and their parasitism rates and temporal variability in parasitism rates (inverse of stability) in 14 traditional agroforests that were specifically chosen to represent a slight intensification gradient, from coffee agroforests with low shade and tree diversity to agroforests with high shade and tree diversity in coastal Ecuador.

\section{Materials and methods}

Study area and sites

The study was carried out in the cantons of Jipijapa, Pajan, and Noboa in Manabi, coastal Ecuador. The study area is situated at 100-550 m a.s.1. (17 N546800m, E9849274m). Annual rainfall is between 1,500 and $1,700 \mathrm{~mm}$, and the annual average temperature is $25^{\circ} \mathrm{C}$. The dry season lasts approximately from June until November. Numerous traditional coffee agroforests are distributed randomly over the landscape, embedded in a mosaic of bushland, secondary forests, pastures, and other agricultural systems such as arable crops (rice, maize). The coffee agroforests consist of coffee planted under a community of various shade tree species, including Leguminosae (Inga sp.), forest remnants or tree species that provide products for local or market subsistence (e.g. fruits, construction materials or timber). For our investigation we chose 14 of these traditional coffee agroforests differing in tree diversity (species richness and Shannon diversity index) and light intensity, thereby representing a slight intensification gradient (Table 1). The distance between sites was always several kilometres (outside of the dispersal range of bee or wasp individuals), thereby reducing the potential for spatial autocorrelation.
Table 1 Sites and values for light intensity (mean value), number of shade tree species, and shade tree diversity (Shannon diversity index)

\begin{tabular}{llrl}
\hline Site number & Light intensity $(\%)$ & Tree species & Tree diversity \\
\hline 1 & 20.7 & 14 & 0.72 \\
2 & 36 & 6 & 0.33 \\
3 & 66.88 & 9 & 0.49 \\
4 & 18.05 & 12 & 0.83 \\
5 & 35.5 & 10 & 0.8 \\
6 & 36 & 5 & 0.22 \\
7 & 46.6 & 12 & 0.94 \\
8 & 17.75 & 10 & 0.91 \\
9 & 32.62 & 12 & 0.73 \\
10 & 38.6 & 8 & 0.62 \\
11 & 60 & 9 & 0.85 \\
12 & 18.1 & 6 & 0.5 \\
13 & 25.9 & 9 & 0.83 \\
14 & 21 & 9 & 0.82 \\
\hline
\end{tabular}

\section{Habitat parameters}

As indicators of habitat and land-use intensity change between agroforests we assessed the two parameters tree diversity (Shannon index) and incident light (light intensity). We measured light intensity with a luxmeter (digital light-gauge with four scopes from $0-1,999 \mathrm{~W} / \mathrm{m}^{2}$; Mavoloux, Gossen) at the edges and in the middle of nine $10 \times 10$-m quadrants (placed in a $3 \times 3$ grid in the centre of each site with a distance of $15 \mathrm{~m}$ between quadrants) and outside the site under open sky to calculate the percentage of incident light in the systems. We sampled trees in nine $10 \times 10-\mathrm{m}$ quadrants and recorded the number of morphospecies and individuals. Because some tree species were represented by only one or few individuals in a site, we calculated the Shannon diversity index as a measure of canopy tree diversity. Tree diversity and incident light were not intercorrelated $(r=-0.1731, P=0.5541)$. Table 1 shows the distribution of light intensity, tree species richness, and tree diversity for each site.

\section{Trap nests}

We provided nesting opportunities for cavity-nesting bees and wasps and their kleptoparasites and parasitoids (hereafter collectively "natural enemies") by establishing traps, which consisted of plastic tubes filled with internodes of reed (Arundo donax L. Poaceae) of different diameters (see Tscharntke et al. 1998; Tylianakis et al. 2005). In each of the 14 study sites we exposed ten traps, five at the approximate layer of coffee shrubs (1.5 $\mathrm{m}$ above ground) and the other five at the approximate height of the herb layer $(0.5 \mathrm{~m}$ above ground), because we initially also 
wanted to test for vertical spatial differences in diversity and parasitism. Traps were hung in branches of coffee shrubs or other shrubs or trees and remained in the field continuously from June 2003 until November 2004. To prevent ants from entering the traps we put sticky glue on the suspension point. Each month we removed occupied reeds and replaced them with empty ones of the same diameter. We reared the occupied reeds in the laboratory until the insects emerged. Insects were identified to subfamily level following Goulet and Huber (1993) for wasps, and Michener (2000) for bees. Genera and species were partly identified by J. Gusenleitner and D. W. Roubik and partly by the authors using keys or reference collections from the Pontificia Universidad Católica del Ecuador. Unidentified species were classified as morphospecies. We noted the number and species of emerging individuals (hereafter either wasp or bee "hosts"), the number of brood cells (individuals) for each wasp and bee morphospecies (abundance), the number of parasitised brood cells, and the number of enemy species and individuals.

\section{Statistical analyses}

All analyses were performed using Statistica 6.1 (StatSoft 2003). We calculated the proportion of brood cells parasitised (hereafter "parasitism rate") for nesting wasps and bees. As there was strong variation in either host or enemy diversity and parasitism rates between months, we calculated the mean of these variables per month ( $n=17$ months). To assess temporal variability in parasitism rate and host and enemy diversity we calculated the coefficient of variation (CV) across months for each of these variables. With general linear models we tested the different dependent variables as follows: species richness of hosts was tested for a relationship with host abundance and the two habitat parameters (light intensity and tree diversity) and trap height. Species richness of enemies was tested for a relationship with enemy abundance, species richness and abundance of their hosts, and also habitat parameters and trap height. Parasitism rate was tested for a relationship with host and enemy diversity, their respective abundance, the two habitat parameters and trap height. Temporal variability in parasitism was tested for a relationship with host and enemy diversity and abundance and, in a second model, for a relationship with temporal variability of host and enemy diversity. We used backward stepwise elimination until only significant variables remained in the model. When trap height had no effect on the tested dependent variables we pooled data from the different heights. To be conservative, we excluded zero values for parasitism (and consequently enemy species richness and abundance) from all analyses, as several zero values for enemy diversity (and hence, parasitism rates) could drive a positive slope to the diversity-parasitism relationship by default. We tested for a normal distribution of residuals and transformed variables if necessary to meet the assumptions of the parametric tests. Proportion parasitism rates were arcsine square root transformed. For plotting single relationships in models that included more than one predictor variable we used the residuals to control for the effect of the other variables in the model.

\section{Results}

In total 26 species nested in the traps, of which 11 were solitary bee species (Apoidea) comprising 1,187 brood cells, six were eumenid wasp species with 2,122 brood cells, seven were sphecid wasp species with 505 brood cells, and two were pompilid wasp species with 1,177 brood cells. We found eight natural enemy species in 250 brood cells feeding on wasp or bee larvae (parasitoids) or their food resources (kleptoparasites). Five percent of all host individuals died due to parasitism. Three enemy species were exclusively found feeding on bees, three exclusively on wasps, and two enemy species fed on both bees and wasps (Table 2).

\section{Host and natural enemy diversity}

Mean species richness was not correlated with light intensity for wasps $\left(r^{2}=0.24, F_{1,13}=3.74, P=0.08\right)$, bees $\left(r^{2}=0.12, F_{1,13}=1.62, P=0.23\right)$, or natural enemies $\left(r^{2}=0.15, F_{1,13}=2.19, P=0.17\right)$. Similarly, shade tree diversity had no significant effect on the species richness of wasps $\left(r^{2}=0.05, F_{1,13}=0.56, P=0.47\right)$, bees $\left(r^{2}=0.03, F_{1,13}=0.31, P=0.55\right)$, or natural enemies $\left(r^{2}=0.04, F_{1,13}=0.51, P=0.49\right)$.

\section{Parasitism rate}

Mean parasitism rate increased with increasing species richness of natural enemies, and decreased with increasing species richness of hosts (Fig. 1a, b), but was not related to their abundances or to habitat parameters. Separation into bees and wasps revealed similar patterns for both guilds. However, for bees the overall model was not significant, presumably due to a lower number of replicates $(n=10)$ (wasps, enemy richness $F_{1,13}=5.79, P<0.05$, host richness $F=9.41, P<0.05$, overall model $r^{2}=0.48, F_{1,13}=5.24, P<0.05$; bees, enemy richness $F_{1,13}=5.49, P<0.05$, host richness $F_{1,13}=5.4$, $P<0.05$, overall model $\left.r^{2}=0.3, F_{1,13}=3.37, P<0.1\right)$.

Temporal variability

Temporal (between month) variability in parasitism rate decreased with increasing species richness of natural 
Table 2 Natural enemy species associated with their host species

\begin{tabular}{|c|c|c|c|}
\hline Enemy family & Enemy species & Host species & Host guild \\
\hline \multirow[t]{2}{*}{ Bombyliidae } & \multirow[t]{2}{*}{ Bombyliidae gen. sp. } & Centris sp. & $\mathrm{B}$ \\
\hline & & Apidae gen. sp. & B \\
\hline \multirow[t]{3}{*}{ Megachilidae } & \multirow[t]{3}{*}{ Coelioxys sp. 1} & Megachile sp. 1 & $\mathrm{~B}$ \\
\hline & & Neofidelia sp. & $\mathrm{B}$ \\
\hline & & Tetrapedia sp. & $\mathrm{B}$ \\
\hline Megachilidae & Coelioxys sp. 2 & Megachile sp. 1 & $\mathrm{~B}$ \\
\hline Meloidea & Meloidae gen. sp. & Pseudodynerus sp. & W \\
\hline \multirow[t]{2}{*}{ Ichneumonidae } & \multirow[t]{2}{*}{ Phygadeuontinae gen. sp. } & Trypoxylon sp. & $\mathrm{W}$ \\
\hline & & Pseudodynerus sp. & W \\
\hline \multirow[t]{4}{*}{ Chrysididae } & \multirow[t]{4}{*}{ Chrysis sp. } & Pompilidae Gen sp. 1 & W \\
\hline & & Monobia angulosa & W \\
\hline & & Pompilidae gen. sp. 2 & W \\
\hline & & Pseudodynerus sp. & W \\
\hline \multirow[t]{6}{*}{ Leucospididae } & \multirow[t]{6}{*}{ Leucospis sp. } & Megachile sp. 1 & $\mathrm{~B}$ \\
\hline & & Neofidelia $\mathrm{sp}$. & $\mathrm{B}$ \\
\hline & & Tetrapedia sp. & B \\
\hline & & Centris sp. & $\mathrm{B}$ \\
\hline & & Eumeninae gen. sp. 1 & $\mathrm{~W}$ \\
\hline & & Pseudodynerus sp. & $\mathrm{W}$ \\
\hline \multirow[t]{11}{*}{ Eulophidae } & \multirow[t]{11}{*}{ Melittobia acasta } & Neofidelia sp. & $\mathrm{B}$ \\
\hline & & Tetrapedia sp. & $\mathrm{B}$ \\
\hline & & Megachile sp. 1 & $\mathrm{~B}$ \\
\hline & & Eumeninae gen. sp. 1 & W \\
\hline & & Zeta sp. & $\mathrm{W}$ \\
\hline & & Sphecidae gen. sp. 1 & W \\
\hline & & Sphecidae gen. sp. 2 & $\mathrm{~W}$ \\
\hline & & Monobia angulosa & W \\
\hline & & Pompilidae gen. sp. 2 & $\mathrm{~W}$ \\
\hline & & Pseudodynerus sp. & W \\
\hline & & Eumeninae gen. sp. 2 & W \\
\hline
\end{tabular}

$B$ Bees, $W$ wasps

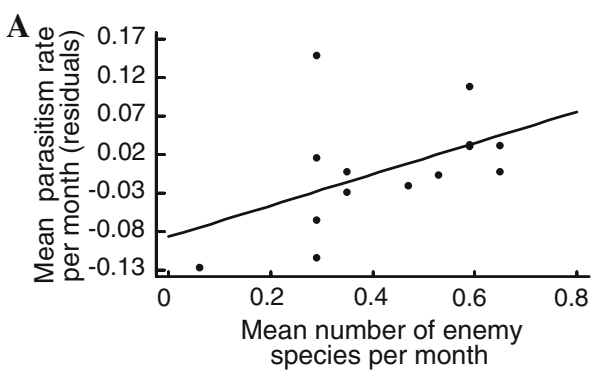

Fig. 1 Relationship between mean parasitism rate per month and a mean species richness of natural enemies per month $\left(F_{1,13}=5,83\right.$, $P<0.05)$ and $\mathbf{b}$ mean species richness of hosts per month $\left(F_{1,13}=8.91, P<0.05\right)$. The overall model with host and enemy

enemies (Fig. 2), and increased with variability in enemy species richness (Fig. 3). It was not related to diversity or abundance of hosts or to temporal variability of host diversity. After separating wasps and bees into the two guilds, it appeared that these patterns were caused by wasps

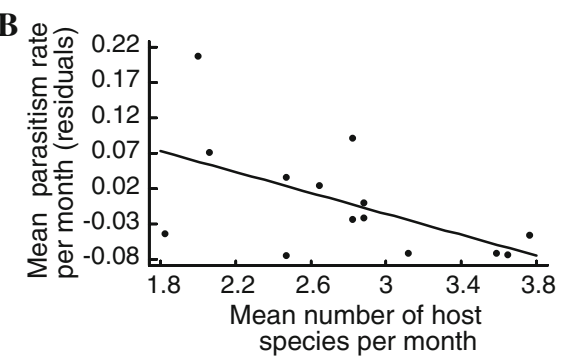

richness was significant $\left(F_{1,13}=4.86, \mathrm{r}^{2}=0.46, P<0.05\right)$. Residuals are taken after removing the effects for $\mathbf{a}$ host and $\mathbf{b}$ natural enemy species richness

(relationship between temporal variability in parasitism of wasps and enemy species richness $r^{2}=0.7, F_{1,13}=29.33$, $P<0.001$; relationship between temporal variability in wasp parasitism and temporal variability in enemy richness $\left.r^{2}=0.94, F_{1,13}=197.66, P<0.0001\right)$. Temporal 


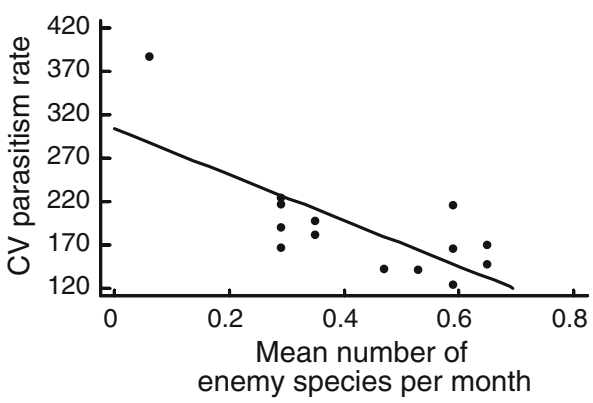

Fig. 2 Relationship between temporal (between-month) variability of parasitism rate [expressed by the coefficient of variation $(\mathrm{CV})$ ] and mean species richness of natural enemies per month $\left(F_{1,13}=13.77\right.$, $\left.r^{2}=0.53, P<0.01\right)$

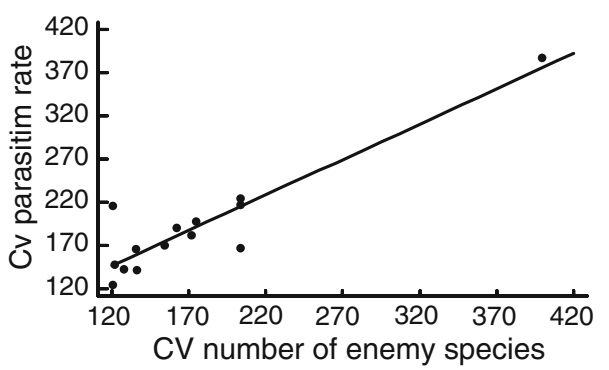

Fig. 3 Relationship between temporal (between-month) variability $(\mathrm{CV})$ of parasitism rate and temporal variability $(\mathrm{CV})$ of parasite species richness $\left(F_{1,13}=64.27, r^{2}=0.82, P<0.0001\right)$

variability in the parasitism rate of bees was significantly positively related to the abundance of enemies attacking bees $\left(r^{2}=0.54, F_{1,13}=11.6, P<0.01\right)$, but not to their species richness $\left(r^{2}=0.25, F_{1,13}=3.36, P=0.10\right)$, nor to temporal variability in enemy richness $\left(r^{2}=0.04\right.$, $F_{1,13}=0.46, P=0.52$ ).

Temporal variability in species richness and abundance was significantly higher for host bees than for wasps (species richness $P<0.0001, F_{1,13}=30.93$; mean $\mathrm{CV}$ bee host species $107.39 \pm 36.06$; mean $C V$ wasp host species $64.95 \pm 12.1$; abundance $P<0.05, F_{1,13}=7.05$; mean CV bee host abundance $147.23 \pm 32.5$; mean $C V$ wasp host abundance $107.7 \pm 42.73$ ), but temporal variability in enemy richness and temporal variability in parasitism rate did not differ between wasps and bees. Temporal variability in the diversity of enemies attacking wasps was not related to temporal variability of host wasp diversity $\left(r^{2}=0.07\right.$, $F_{1,13}=0.99, P=0.34$ ), but temporal variability in the diversity of enemies attacking bees was significantly positively related to temporal variability in diversity of bee hosts (bees: $r^{2}=0.51, F_{1,13}=10.49, P<0.01$ ).

\section{Discussion}

Parasitism rates of cavity-nesting wasps and bees were found to be positively related to the diversity of their natural enemy species. In addition, parasitism rates of wasps and bees were significantly negatively related to the number of wasp and bee species but not to their abundances. The results of a positive relationship between enemy diversity and parasitism support theoretical and experimental evidence for a diversity-function relationship in multitrophic systems (e.g. Cardinale et al. 2003; Gamfeldt et al. 2005; Ives et al. 2005; Tylianakis et al. 2006). The general mechanisms driving positive biodiversityfunction relationships range from complementarity in niche use between functional groups or species, facilitation by interspecific interactions between functional groups or species, to sampling effects (Hooper et al. 2005; Klein et al. 2008). An increase in parasitism rate may be attributed to niche complementarity among natural enemy species, by increasing host resource partitioning (Lehman and Tilman 2000; Long et al. 2007; Casula et al. 2006). Most enemy species fed on no more than one to six wasp or bee host species. Therefore an increased number of enemy species should have resulted in an enhanced overall consumption (Lehman and Tilman 2000). The only exception was a gregarious parasitoid species (Melittobia acasta) feeding on 13 different host species (11 wasps and two bees). Further, functional diversity of enemies, including differences between solitary and gregarious parasitoids and kleptoparasites, may have increased consumption rates.

A negative relationship between parasitism and host diversity was also found, thereby showing that the diversity-function relationship may be driven by diversity at more than one trophic level (Hooper et al. 2005). A high number of host wasp and bee species may have decreased their rate of parasitism by enemies. Higher host diversity can imply an increased number of inedible species, thereby reducing overall consumption effects and increasing resistance against parasitism (Hillebrand and Cardinale 2004). Resource concentration in the density of hosts seems not to lead to a positive diversity-parasitism relationship in this study as host abundance was not related to overall parasitism rates. In general, the results confirm the study of Tylianakis et al. (2006) which was conducted in the same study area but in different study sites comprising a broader land-use gradient compared to this study, which comprised a finer gradient in only one agricultural system (coffee agroforestry). Hence, positive diversity-parasitism relationships may be a general ecological phenomenon in natural bee and wasp communities and can be found in and between habitat types.

The results also support the expectation that diversity can stabilise ecosystem functioning (Lehman and Tilman 2000) in multitrophic systems, as temporal variability of wasp parasitism rates decreased with increasing species richness of enemies. These results differ from those found by Rodríguez and Hawkins (2000), who did not find such 
stabilizing effects of diversity in a natural enemy community that was, in contrast to this study, functionally extremely homogeneous. Because different species may respond differently to environmental changes, a diverse and functionally heterogeneous predator community may ensure a stable ecosystem function, such as predation over time, by compensating for species losses in temporarily less favourable environmental conditions (Tilman and Downing 1994; Lehman and Tilman 2000; Winfree and Kremen 2009). Thereby, biodiversity acts as a biological insurance for ecosystem processes (Thébault and Loreau 2005). However, the number of enemy species was not related to temporal variation in bee parasitism. This may be linked to the relatively high variability in bee host species richness and abundance in comparison to wasp hosts, which in turn may be caused by the high temporal variability of floral resource availability in the study region.

In accordance with Tylianakis et al. (2006), temporal variability of the number of enemy species attacking wasps was also positively related to the temporal variability of parasitism rate. The lower the variation is within a functional group, the more likely it can provide a constant ecosystem service. But temporal variability of the number of enemy species was not related to temporal variability of bee parasitism rate. Similarly, the high temporal variability of bee hosts might have blurred the effect of a temporally stable natural enemy community on the temporal stability of parasitism rates.

We infer from our correlative results that a high number of enemy species may contribute to increased overall parasitism rates in a single agricultural system and this may apply for hosts as different as pollinators and predators. At a lower trophic level, diversity may also reduce attack rates in a multitrophic system, because increasing prey diversity could limit parasitism and therefore act as resistance against consumption in both host guilds. In addition, these results show that a diverse and stable enemy community may stabilize parasitism rates. However, these effects may be host-guild specific and influenced by resource-mediated temporal variation in host communities. Positive diversityparasitism function and diversity-parasitism stability relationships seem to be general in natural bee and wasp communities and can be found in and between habitat types. Further, experimental analyses including manipulated diversity levels in the same system may strengthen our correlative results and detect possible mechanisms.

Acknowledgments We would like to thank Dr Giovanni Onore for the use of the bee and wasp collection at the Universidad Catolica in Quito for further identification, Free de Koning, Roland Olschewski, and Betty Pico Díaz of the BIO-SYS project (Evaluation of biological diversity of land-use systems in a mega-diverse region of Ecuador) for their support and help, and Tannya Lozada for help with tree data collection. We are thankful to Gricel Sacoto, Jubian Casquete, Jose
Pico, Cesar Calderon, Angel Chóez, and Jesus Lino for field and laboratory assistance, and to all Ecuadorian smallholders in and around Jipijapa for their permission to work in their "cafetales". We also greatly acknowledge helpful comments provided by Bernard Schmidt and one anonymous referee on a previous draft of the manuscript. Finally, we would like to thank the Deutsche Gesellschaft für technische Zusammenarbeit (GTZ) for their cooperation and the German Ministry of Education and Research (BMBF) for the financial support. The experiments described here comply with the current laws of the country in which they were performed.

Open Access This article is distributed under the terms of the Creative Commons Attribution Noncommercial License which permits any noncommercial use, distribution, and reproduction in any medium, provided the original author(s) and source are credited.

\section{References}

Aoki I, Mizushima T (2001) Biomass diversity and stability of food webs in aquatic ecosystems. Ecol Res 16:65-71

Armbrecht I, Rivera L, Perfecto I (2005) Reduced diversity and complexity in the leaf-litter ant assemblage of Colombian coffee plantations. Conserv Biol 19:887-907

Briggs CJ, Latto J (2000) The effects of dispersal on the population dynamics of the gall-forming midge and its parasitoids. J Anim Ecol 69:96-105

Cardinale BJ, Harvey CT, Gross K, Ives AR (2003) Biodiversity and biocontrol: emergent impacts of a multi-parasite assemblage on pest suppression and crop yield in an agroecosystem. Ecol Lett 6:857-865

Cardinale BJ, Wright JP, Cadotte MW, Carroll IT, Hector A, Srivastava DS, Loreau M, Weis JJ (2008) Impacts of plant diversity on biomass production increase through time because of species complementarity. Proc Natl Acad Sci USA 104:18123-18128

Casula P, Wilby A, Thomas MB (2006) Understanding biodiversity effects on prey in multi-parasite systems. Ecol Lett 9:995-1004

Daily GC, Alexander S, Ehrlich P, Goulder L, Lubchenco J, Matson PA, Mooney HA, Postel S, Schneider SH, Tilman D, Woodwell GM (1997) Ecosystem services: benefits supplied to human societies by natural ecosystems. Ecology 2:1-16

Diaz S, Fargione J, Chapin FS, Tilman D (2006) Biodiversity loss threatens human wellbeing. Plos Biol 4:1300-1305

Ehler LE (1992) Guild analysis in biological control. Environ Entomol 21:26-40

Gamfeldt L, Hillebrand H, Jonsson PR (2005) Species richness changes across two trophic levels simultaneously affect prey and consumer biomass. Ecol Lett 8:696-703

Gathmann A (1998) Bienen, Wespen und ihre Gegenspieler in der Agrarlandschaft: Artenreichtum und Interaktionen in Nisthilfen, Aktionsradien und Habitatbewertung. Cuvillier, Göttingen, Germany

Goulet H, Huber JT (1993) Hymenoptera of the world: an identification guide to families, IV series. Agriculture Canada: research branch, Canada

Hillebrand H, Cardinale BJ (2004) Consumer effects decline with prey diversity. Ecol Lett 7:192-201

Hooper DU, Chapin FS, Ewel JJ, Hector A, Inchausti P, Lavorel S, Lawton JH, Lodge DM, Loreau M, Naeem S, Schmid B, Setälä H, Symstad AJ, Vandermeer J, Wardle DA (2005) Effects of biodiversity on ecosystem functioning: a consensus of current knowledge. Ecol Monogr 75:3-35

Ives AR, Cardinale BJ, Snyder WE (2005) A synthesis of subdisciplines: predator-prey interactions, and biodiversity and ecosystem functioning. Ecol Lett 8:102-116 
Klein AM, Steffan-Dewenter I, Tscharntke T (2003) Pollination of Coffea canephora in relation to local and regional agroforestry management. J Appl Ecol 40:837-845

Klein AM, Steffan-Dewenter I, Tscharntke T (2006) Rainforest promotes trophic interactions and diversity of trap-nesting Hymenoptera in adjacent agroforestry. J Anim Ecol 75:315-323

Klein AM, Cunningham SA, Bos M, Steffan-Dewenter I (2008) Advances in pollination ecology from tropical plantation crops. Ecology 89:935-943

Larsen TH, Williams NM, Kremen C (2005) Extinction order and altered community structure rapidly disrupt ecosystem functioning. Ecol Lett 8:538-547

Lehman C, Tilman D (2000) Biodiversity, stability, and productivity in competitive communities. Am Nat 156:534-552

Long ZT, Bruno JF, Duffy JE (2007) Biodiversity mediates productivity through different mechanisms at adjacent trophic levels. Ecology 88:2821-2829

Mas AH, Dietsch T (2003) An index of management intensity for coffee agroecosystems to evaluate butterfly species richness. Ecol Appl 13:1491-1501

Michener CD (2000) The bees of the world. The Johns Hopkins University Press, Baltimore

Moguel P, Toldeo VM (1999) Biodiversity conservation in traditional coffee systems of Mexico. Conserv Biol 13:11-21

Montoya JM, Rodriguez MA, Hawkins BA (2003) Food web complexity and higher-level ecosystem services. Ecol Lett 6:587-593

Perfecto I, Mas A, Dietsch T, Vandermeer JH (2003) Conservation of biodiversity in coffee agroecosystems: a tri-taxa comparison in southern Mexico. Biodiv Conserv 12:1239-1252

Petchey OL, Downing AL, Mittelbach GG, Persson L, Steiner CF, Warren P, Woodward G (2004) Species loss and the structure and functioning of multitrophic aquatic systems. Oikos 104:467-478

Philpott SM, Arendt WJ, Armbrecht I, Bichier P, Dietsch TV, Gordon C, Greenberg R, Perfecto I, Reynoso-Santos R, Soto-Pinto L, Tejeda-Cruz C, Williams-Linera G, Valenzuela J, Zolotoff JM (2008) Biodiversity loss in Latin American coffee landscapes: review of the evidence on ants, birds, and trees. Conserv Biol 22:1093-1105

Rodríguez MA, Hawkins B (2000) Diversity, function and stability in parasite communities. Ecol Lett 3:35-40

Schmid B, Balvanera P, Cardinale BJ, Godbold J, Pfisterer AB, Raffaelli D, Solan M, Srivastava DS (2009) Consequences of species loss for ecosystem functioning: meta-analyses of data from biodiversity experiments. In: Naeem S, Bunker DE,
Hector A, Loreau M, Perrings C (eds) Biodiveristy, ecosystem functioning, and human wellbeing-an ecological and economic perspective. Oxford University Press, New York, pp 14-30

Sih A, Englund G, Wooster D (1998) Emergent impacts of multiple predators on prey. Trends Ecol Evol 13:350-356

Snyder WE, Finke DL, Straub CS (2006) Predator diversity strengthens herbivore suppression. Ecol Lett 9:789-796

Srivastava DS, Vellend M (2005) Biodiversity-ecosystem function research: is it relevant to conservation? Annu Rev Ecol Evol S 36:267-294

StatSoft Inc (2003) STATISTICA (data analysis software system), version 6. http://www.statsoft.com

Straub CS, Finke DL, Snyder WE (2008) Are the conservation of natural enemy biodiversity and biological control compatible goals? Biol Control 45:225-237

Thébault E, Loreau M (2005) Trophic interactions and the relationship between species diversity and stability. Am Nat 166:E95E114

Thébault E, Loreau M (2006) The relationship between biodiversity and ecosystem functioning in food webs. Ecol Res 21:17-25

Tilman D, Downing JA (1994) Biodiversity and stability in grasslands. Nature 367:363-365

Tilman D, Wedin D, Knops J (1996) Productivity and sustainability influenced by biodiversity in grassland ecosystems. Nature 379:718-720

Tscharntke T, Gathmann A, Steffan-Dewenter I (1998) Bioindication using trap-nesting bees and wasp and their natural enemies: community structure and interactions. J Appl Ecol 35:708-719

Tylianakis JM, Klein AM, Tscharntke T (2005) Spatiotemporal variation in the diversity of Hymenoptera across a tropical habitat gradient. Ecology 86:3296-3302

Tylianakis JM, Tscharntke T, Klein AM (2006) Diversity, ecosystem function, and stability of parasite-host interactions across a tropical gradient of habitat modification. Ecology 87:3047-3057

Tylianakis JM, Rand TA, Kahmen A, Klein AM, Buchmann N, Perner J, Tscharntke T (2008) Resource heterogeneity moderates the biodiversity-function relationship in real world ecosystems. PLoS Biol 6:e122, 947-956

Vergara CH, Badano EI (2008) Pollinator diversity increases fruit production in Mexican coffee plantations: the importance of rustic management systems. Agric Ecosyst Environ 129:117-123

Winfree R, Kremen C (2009) Are ecosystem services stabilized by differences among species? A test using crop pollination. Proc R Soc B Biol 276:229-237. doi:10.1098/rspb.2008.0709 